\title{
Factors affecting the success rate of open lacrimal surgery
}

\author{
Mark J Walland, Geoffrey E Rose
}

\begin{abstract}
Postoperative soft tissue infection may predispose to failure of open lacrimal surgical procedures. Using a retrospective analysis of 413 cases, the failure rates for primary and repeat surgery were $12.0 \%$ and $8.9 \%$ respectively $(0.25<\mathrm{p}<0.5)$. Postoperative soft tissue infection is associated with an increased risk of failure ( $p<0.005)$; antibiotics decrease the rate of postoperative infection and may thus decrease the failure rate. Furthermore, antibiotic therapy decreases the rate of failure in cases after previous facial trauma. Curative antibiotic therapy for established postoperative infection is less effective than preventative therapy at improving the success rate after surgery. Previous trauma is also associated with a greater rate of failure $(p<0.02)$, possibly owing to the frequent canalicular problems in such patients. Silicone tubes appear to increase neither the rate of infection nor failure (p>0.5). Trauma, acute dacryocystitis, and silicone tubes appear to act on outcome independently of each other.

(Brf Ophthalmol 1994; 78: 888-891)
\end{abstract}

After open lacrimal surgery, soft tissue infection occurs in about $8 \%$ of cases, but in $1.6 \%$ (or less) of cases where prophylactic postoperative oral antibiotics are used. ${ }^{\prime}$ The current study was performed to assess whether postoperative infection had any effect on the success rate and to determine the influence of related factors on the surgical outcome.

\footnotetext{
Methods

The notes for 413 cases (370 patients) were reviewed, with particular attention to any preoperative history of acute dacryocystitis or facial trauma (such as mid-facial fractures or canalicular laceration), the type and outcome of surgery, the use of silicone tubes or postoperative antibiotics, and any evidence of postoperative infection.

The open lacrimal surgery considered was dacryocystorhinostomy (DCR) or canaliculoDCR, as well as reoperation for these procedures; insertions of Lester Jones tubes were excluded. Bilateral surgery in 43 patients, whether simultaneous or consecutive, was considered as two cases. Intranasal surgery, such as turbinectomy, was needed only rarely and
}

postoperative nasal packing was almost never required.

Failure was regarded as recurrence of epiphora (other than that associated with environmental irritants or upper respiratory tract infection), or clinical (and often also radiological) evidence of failure of the surgical fistula - as with negative dye disappearance or Jones I tests. A case was regarded as infected if there was marked or widespread cellulitis around the incision or the formation of an abscess; other signs such as nasal discharge or haemorrhage were not regarded as indicators of infection. Microbiological culture was attempted in very few cases as most had cellulitis (rather than frank abscess formation) or many had been commenced on antibiotics by their general practitioner.

The cases fall into two consecutive groups, based on a decision (instituted during the study period March 1989-August 1992) to give prophylactic early postoperative systemic antibiotics for all cases of open lacrimal surgery. While not randomised, the two groups were of similar case mix and management (other than antibiotic use) and selection bias is thus unlikely. The latter patients were generally prescribed a 5 day course of either cephalexin $(67 \%)$ or erythromycin (18\%), without observed side effects. Three cases intended for prophylaxis received no treatment because of known drug allergies. In the group for which no prophylaxis was planned, 32 were given treatment because of perceived clinical necessity, resulting in 208 (50\%) cases who did, and $205(50 \%)$ cases who did not receive prophylactic systemic antibiotics. All patients received a 2-3 week course of topical antibiotic drops.

$\chi^{2}$ Analysis was used as a test of statistical significance. Given the retrospective nature of the data, multivariate analysis was not performed.

\section{Results}

Analysis of 413 cases undergoing surgery during the period of the study provides an overview of the type and success of this surgery in a major teaching and tertiary referral centre. Primary surgery comprised $324 / 413(78 \%)$ cases and repeat surgery $89 / 413(22 \%)$ cases. There were $156(38 \%)$ males and $257(62 \%)$ females with mean ages of 40 and 49 years, respectively (range 1-90 years); 52 cases were aged 10 years or less.

The overall failure rate was $47 / 413(11 \%)$ : the 
Table 1 Rate of failure in relation to preoperative, intraoperative, and postoperative factors

\begin{tabular}{|c|c|c|c|}
\hline & \multicolumn{3}{|l|}{ Failure rate } \\
\hline & $\begin{array}{l}\text { Primary } \\
\text { surgery }\end{array}$ & $\begin{array}{l}\text { Repeat } \\
\text { surgery }\end{array}$ & $\begin{array}{l}\text { All types } \\
\text { surgery }\end{array}$ \\
\hline \multicolumn{4}{|l|}{ Overall group: } \\
\hline $\begin{array}{l}\text { Whole group } \\
\text { With antibiotics } \\
\text { No antibiotics }\end{array}$ & $\begin{array}{l}39 / 324(12 \%) \\
20 / 169(12 \%) \\
19 / 155(12 \%)\end{array}$ & $\begin{array}{l}8 / 89(9 \%) \\
3 / 39(8 \%) \\
5 / 50(10 \%)\end{array}$ & $\begin{array}{l}47 / 413(11 \%) \\
23 / 208(11 \%) \\
24 / 205(12 \%)\end{array}$ \\
\hline \multicolumn{4}{|c|}{ Preoperative trauma: } \\
\hline $\begin{array}{l}\text { Whole subgroup } \\
\text { With antibiotics } \\
\text { No antibiotics }\end{array}$ & $\begin{array}{l}8 / 32(25 \%)^{d} \\
3 / 16(19 \%)^{f} \\
5 / 15(31 \%)^{d}\end{array}$ & $\begin{array}{l}1 / 6(17 \%)^{f} \\
0 / 3^{g} \\
1 / 3(33 \%)^{f}\end{array}$ & $\begin{array}{l}9 / 38(24 \%)^{d} \\
3 / 19(16 \%)^{f} \\
6 / 19(32 \%)^{b}\end{array}$ \\
\hline \multicolumn{4}{|c|}{ Previous acute dacryocystitis: } \\
\hline $\begin{array}{l}\text { Whole subgroup } \\
\text { With antibiotics } \\
\text { No antibiotics }\end{array}$ & $\begin{array}{l}5 / 44(11 \%)^{\mathrm{g}} \\
3 / 27(11 \%)^{\mathrm{g}} \\
2 / 17(12 \%)^{\mathrm{g}}\end{array}$ & $\begin{array}{l}1 / 22(5 \%)^{f} \\
1 / 11(9 \%)^{g} \\
0 / 11^{f}\end{array}$ & $\begin{array}{l}6 / 66(9 \%)^{\mathrm{g}} \\
4 / 38(11 \%)^{\mathrm{g}} \\
2 / 28(7 \%)^{\mathrm{f}}\end{array}$ \\
\hline \multicolumn{4}{|c|}{ Silicone intubation: } \\
\hline $\begin{array}{l}\text { Whole subgroup } \\
\text { With antibiotics } \\
\text { No antibiotics }\end{array}$ & $\begin{array}{l}21 / 178(12 \%)^{\mathrm{g}} \\
11 / 95(12 \%)^{\mathrm{g}} \\
10 / 83(12 \%)^{\mathrm{g}}\end{array}$ & $\begin{array}{l}6 / 75(8 \%)^{f} \\
3 / 36(8 \%)^{\mathrm{g}} \\
3 / 39(8 \%)^{\mathrm{f}}\end{array}$ & $\begin{array}{l}27 / 253(11 \%)^{g} \\
14 / 131(11 \%)^{g} \\
13 / 122(11 \%)^{g}\end{array}$ \\
\hline \multicolumn{4}{|c|}{ Postoperative infection: } \\
\hline $\begin{array}{l}\text { Whole subgroup } \\
\text { With antibiotics } \\
\text { No antibiotics }\end{array}$ & $\begin{array}{l}5 / 13(38 \%)^{b} \\
1 / 2(50 \%)^{\mathrm{e}} \\
4 / 11(36 \%)^{d}\end{array}$ & $\begin{array}{l}1 / 6(17 \%)^{f} \\
1 / 4(25 \%)^{f} \\
0 / 2^{g}\end{array}$ & $\begin{array}{l}6 / 19(32 \%)^{b} \\
2 / 6(33 \%)^{e} \\
4 / 13(31 \%)^{d}\end{array}$ \\
\hline
\end{tabular}

Significance levels (as abbreviated) relate to the overall failure rate at the head of each column.

${ }^{\mathrm{a}} \mathrm{p}<0.001 ;{ }^{\mathrm{b}} 0.001<\mathrm{p}<0.005 ;{ }^{\mathrm{c}} 0.005<\mathrm{p}<0.01 ;{ }^{\mathrm{d}} 0.01<\mathrm{p}<0.05$; ${ }_{0}^{\mathrm{p}} 0.05<\mathrm{p}<0.10 ;{ }^{\mathrm{f}} 0 \cdot 10<\mathrm{p}<0.50 ;{ }^{\mathrm{g}} \mathrm{p}>0.5$.

rate was $39 / 324(12 \%)$ cases for primary and $8 / 89$ $(8.9 \%)$ cases for repeated surgery $(0.25<\mathrm{p}<0.5$; Table 1).

Previous acute dacryocystitis was not a risk for failure $(6 / 66(9 \cdot 1 \%)$ cases; $p>0 \cdot 5)$. However, prior trauma was associated with an increased failure rate $(9 / 38(24 \%)$ cases) compared with $38 /$ $375(10 \%)$ cases without trauma $(\mathrm{p}<0.02$; Table 1). There were 19 infected cases, of which six (32\%) failed, this contrasting with a failure rate of $10 \%(41 / 394)$ in non-infected cases $(p<0.005)$. For primary surgery alone, $5 / 13(38 \%)$ of infected cases failed compared with $34 / 311(11 \%)$ of non-infected cases $(p<0.005)$; for repeated surgery, rates were $1 / 6(17 \%)$ compared with $7 / 83(8.4 \%)(0.25<\mathrm{p}<0.5$; Table 1$)$. The failure rates with $(27 / 253 ; 11 \%)$ and without $(20 / 160$; $13 \%)$ intubation were similar ( $p>0.5$; Table 1$)$.

\section{Discussion}

The failure rate for primary surgery was $12 \%$ and for repeat surgery $8.9 \%$, the probable explanation being that this series was derived from a teaching hospital where primary surgery is largely performed by training grades, while repeated surgery is more often done by a consultant surgeon. The choice of operation in the presence of canalicular disease may also be important (see below).

Of 41 cases of DCR failure reviewed by Welham and Henderson, ${ }^{2} 19$ were due to occlu- sion distal to the canaliculi (attributed to small ostia, scarring from non-suture of flaps or a reaction to silk sutures), common canalicular block ( 16 cases), 'sump syndrome' (three cases), and no entry into the nose (three cases).

Soft tissue infection does occur after open lacrimal surgery ${ }^{1}$ and it has been suggested that poorly apposed mucosal flaps may predispose to infection. ${ }^{3}$ In the present series, however, a problem was recorded with the suturing of the anastomosis in only one of the 19 infected cases this procedure failing. It would appear, therefore, that infection or failure can occur despite adequately secured mucosal flaps.

We sought to ascertain whether prior trauma, previous acute dacryocystitis, silicone intubation, the use of postoperative antibiotics or postoperative infection modify the risk for failure.

\section{TRAUMA}

Failure is commoner after trauma (9/38 (24\%) failures) than in cases without trauma $(38 / 375$ (10\%) failures; $\mathrm{p}<0.02$; Table 1 ); a risk also for primary surgery alone $(p<0.02$; Table 1$)$ and for cases not receiving antibiotic prophylaxis $(6 / 19$ (32\%) failures with trauma, 18/186 (10\%) failures without trauma; $\mathrm{p}<0.005$; Table 1 ). Prior trauma predisposes to postoperative soft tissue infection ${ }^{1}$ but, paradoxically, the failure rate after trauma was similar in the infected (1/4 $(25 \%)$ cases) and uninfected ( $8 / 34(24 \%)$ cases; p $>0.5$; Table 2 ); a result suggesting that preceding trauma may predispose independently to both failure and infection. Canalicular disease consequent, for example, upon medial canthal injury, probably contributed to failure in at least five of the nine trauma failures, whereas infection in cases with previous trauma probably accounted for only 2/9 failures; in corroboration, Lester Jones canalicular bypass tubes were inserted in $25 \%$ of trauma cases compared with $8.3 \%$ of other cases over the period of the study $(\mathrm{p}<0.001)$

Post-traumatic cases were not associated with a bias in the use of either antibiotic prophylaxis or silicone intubation (Table 2). Neither previous acute dacryocystitis nor silicone intubation predisposed trauma cases to failure $(0 \cdot 25<\mathrm{p}<0.5 ;$ Table 2$)$.

\section{ACUTE DACRYOCYSTITIS}

Sixty six of $413(16 \%)$ cases had prior acute dacryocystitis and eight $(12 \%)$ of these developed

Table 2 Rate of failure in relation to various combinations of two risk factors

\begin{tabular}{|c|c|c|c|c|c|c|c|c|}
\hline & \multicolumn{2}{|c|}{ Prior acute dacryocystitis } & \multicolumn{2}{|l|}{ Intubation } & \multicolumn{2}{|l|}{ Antibiotics } & \multicolumn{2}{|c|}{ Postoperative infection } \\
\hline & Yes & No & Yes & No & Yes & No & Yes & No \\
\hline \multicolumn{9}{|l|}{ Trauma } \\
\hline $\begin{array}{l}\text { Yes } \\
\text { No }\end{array}$ & $\begin{array}{l}1 / 7(14 \%) \\
5 / 59(8 \%)\end{array}$ & $\begin{array}{c}8 / 31(26 \%) \\
33 / 316(10 \%)\end{array}$ & $\begin{array}{r}7 / 24(29 \%) \\
20 / 229(9 \%)\end{array}$ & $\begin{array}{c}2 / 14(14 \%) \\
18 / 146(12 \%)\end{array}$ & $\begin{array}{c}3 / 19(16 \%) \\
20 / 189(11 \%)\end{array}$ & $\begin{array}{c}6 / 19(32 \%) \\
18 / 186(10 \%)\end{array}$ & $\begin{array}{l}1 / 4(25 \%) \\
5 / 15(33 \%)\end{array}$ & $\begin{array}{r}8 / 34(24 \%) \\
33 / 360(9 \%)\end{array}$ \\
\hline \multicolumn{9}{|c|}{ Acute dacryocystitis } \\
\hline $\begin{array}{l}\text { Yes } \\
\text { No }\end{array}$ & - & - & $\begin{array}{c}2 / 28(7 \%) \\
25 / 225(11 \%)\end{array}$ & $\begin{array}{c}4 / 38(11 \%) \\
16 / 122(13 \%)\end{array}$ & $\begin{array}{c}4 / 38(11 \%) \\
19 / 170(11 \%)\end{array}$ & $\begin{array}{c}2 / 28(7 \%) \\
22 / 177(12 \%)\end{array}$ & $\begin{array}{l}3 / 8(38 \%) \\
3 / 11(27 \%)\end{array}$ & $\begin{array}{c}3 / 58(5 \%) \\
38 / 336(11 \%)\end{array}$ \\
\hline $\begin{array}{l}\text { Iubes } \\
\text { Yes }\end{array}$ & - & - & \multicolumn{6}{|c|}{ Tubes } \\
\hline No & - & - & - & - & $9 / 77(12 \%)$ & $11 / 83(13 \%)$ & $4 / 9(44 \%)$ & $16 / 151(11 \%)$ \\
\hline \multicolumn{9}{|l|}{ Antibiotics } \\
\hline No & - & - & - & - & $\begin{array}{l}- \\
-\end{array}$ & $\begin{array}{l}- \\
-\end{array}$ & $4 / 13(31 \%)$ & $20 / 192(10 \%)$ \\
\hline
\end{tabular}


postoperative infection compared with 11/347 $(3 \cdot 2 \%)$ cases without prior acute dacryocystitis $(\mathrm{p}<0.005)$; where antibiotics were given, $5 / 38$ (13\%) cases with antecedent acute dacryocystitis developed infection, compared with $1 / 170$ $(0.6 \%)$ without dacryocystitis $(\mathrm{p}<0.001$; Table 2 ); in patients not receiving antibiotics, the rates of infection were similar in the presence or absence of acute dacryocystitis $(11 \%$ and $6 \%$ respectively; $0.25<\mathrm{p}<0.5$ ). As postoperative antibiotics were used in $58 \%$ of patients with acute dacryocystitis and $49 \%$ without acute dacryocystitis, this suggests that antibiotics are most effective at preventing infection (and significantly so) in cases without antecedent acute dacryocystitis; the probability of bias in selection of more severe acute dacryocystitis cases for antibiotic administration (see above) must, however, be recognised.

After acute dacryocystitis, there were $6 / 66$ $(9 \cdot 1 \%)$ failures compared with $41 / 347(12 \%)$ failures in the other group ( $p>0.5$; Table 1); of eight acute dacryocystitis cases who developed postoperative infection, however, $3 / 8$ (38\%) failed $(\mathrm{p}<0.005$; Table 2$)$. No difference in outcome was evident in relation to antibiotic usage (Table 2). Silicone tubes were used less in cases after acute dacryocystitis $(p<0.001)$ and their usage did not appear to affect outcome. No association was apparent between the incidence of trauma and the occurrence of preoperative acute dacryocystitis (Table 2 ).

\section{SILICONE INTUBATION}

The role of silicone intubation in lacrimal surgery has been discussed recently, ${ }^{46}$ it being suggested that intubation may increase the risk of failure.

When failure was attributable to common canalicular blockage in the present study, it had generally been the case that a DCR with intubation was undertaken initially (while recognising a poor prognosis) in an attempt to avoid Jones tube insertion, with its recognised difficulties and need for long term aftercare. ${ }^{7}$ While residual canalicular disease accounted for 25/47 (53\%) failures in our series, a number of patients with known canalicular scarring achieved successful outcome with DCR/intubation, suggesting that this management approach may successfully avoid placement of a Lester Jones tube in some patients.

Silicone intubation was placed in $253(61 \%)$ cases, there being no difference in the failure rates with $(27 / 253 ; 11 \%)$ or without $(20 / 160$; $13 \%)$ intubation $(\mathrm{p}>0.5)$ : with primary surgery, $178 / 324(55 \%)$ were intubated and the failure rates were, likewise, not significantly different $(21 / 178(12 \%)$ failures with or $18 / 146(12 \%)$ failures without intubation; $p>0.5$; Table 1 ). Intubation was more frequently used in cases for repeated surgery $(75 / 89(84 \%) ; \mathrm{p}<0.001)$; failure rates were $6 / 75(8 \cdot 0 \%)$ compared with $2 / 14(14 \%)$ without intubation $(0.25<\mathrm{p}<0.5$; Table 1$)$.

Intubation was performed in $131(63 \%)$ of the 208 patients receiving prophylaxis and 14/131 (11\%) failed, whereas of the $60 \%(122 / 205)$ intubated in the non-antibiotic group, 13/122 ( $11 \%)$ failed ( $p>0.5$, Table 1$)$; that is, antibiotics do not influence the rate of failure in the presence of intubation, a finding consistent with a previous report concerning intubation and postoperative infection.' Intubation would not appear to be a major risk factor for failure.

\section{ANTIBIOTIC PROPHYLAXIS}

It has been demonstrated previously that a significant reduction in soft tissue infection can be obtained with postoperative antibiotic prophylaxis, ${ }^{1}$ but prophylaxis does not appear to be directly related to failure $-23 / 208(11 \%)$ failing in the presence of and 24/205 (12\%) failing in the absence of antibiotic prophylaxis $(p>0.5$; Table 1).

It was considered imperative to give antibiotic prophylaxis to 32 cases during the period of 'nonprophylaxis', these cases constituting particularly 'at risk' or 'difficult' patients. Inclusion of such 'difficult' patients - at higher risk of both infection and failure - into the 'prophylaxis' group would be expected to increase the failure rate in this group. Indeed, their inclusion doubled the number of infections (from 3/176 $(1 \cdot 7 \%)$ to $6 / 208(2 \cdot 9 \%))$ in the antibiotic prophylaxis group.

Among 13 patients receiving antibiotics only after established infection (that is, from the 'infection cured' group) there were five (38\%) failures, this contrasting with 18/176 failures $(10 \%)$ in the planned prophylaxis ('infection prevented') group $(p<0.005)$. Prevention of infection appears, therefore, to be associated with a greater success rate than the treatment of established infection, although it is unclear whether infection is the cause of failure, or whether patients with surgery liable to fail are more likely to become infected.

\section{POSTOPERATIVE SOFT TISSUE INFECTION}

Infection occurred in $19 / 413(4 \cdot 6 \%)$ cases and the rate of failure was greater for infected cases $(6 / 19$ $(32 \%))$ than for uninfected ones $(41 / 394(10 \%)$; $\mathrm{p}<0.005$; Table 1$)$. The result appears related to differences with primary surgery $(5 / 13$ failures $(38 \%) ; \mathrm{p}<0.005)$ rather than after repeated surgery $(1 / 6$ failures $(17 \%) ; 0 \cdot 25<\mathrm{p}<0.5)$. It remains unclear, however, whether postoperative infection is the cause or effect of failure: does infective inflammation and oedema cause scarring of the operative anastomosis (and failure) or does inadequate surgical technique or more operative trauma (increasing the risk of failure) also predispose to soft tissue infection? The greater influence of infection on outcome in the non-antibiotic group $(\mathrm{p}<0.05)$ compared with those receiving antibiotics $(0.05<\mathrm{p}<0 \cdot 10$; Table 2 ), might suggest that infection predisposes to failure.

Cases becoming infected are clearly associated with a higher risk of failure $(p<0.005)$ and infection may be the causal factor; furthermore, both trauma and previous acute dacryocystitis are associated with a greater risk of infection and infection may, therefore, contribute to the increased risk of failure in both groups.

Because the risk of infection can be decreased by antibiotic prophylaxis' ${ }^{1}$ and repeated surgery 
is a complex procedure, we recommend that all patients undergoing open lacrimal surgery should receive antibiotic prophylaxis.

The antibiotics selected for prophylaxis are worthy of consideration: cephalexin or erythromycin were generally used in this study and provide excellent cover against Gram positive organisms, but are less potent against Gram negative organisms. In cases after acute dacryocystitis where a pure culture was obtained from sac contents sampled at the time of surgery, $65 \%$ grew Gram positive isolates, $27 \%$ Gram negatives, and $7 \%$ anaerobes; some infections may not, therefore, be covered adequately by our current regimen. There is, however, no relation between the organisms cultured from the lacrimal sac and the nasal or conjunctival surfaces.' Furthermore, single dose therapy or peroperative intravenous therapy $^{10}$ may be a more effective prophylaxis.
We thank Mr Richard Welham for his care of many of these patients.

1 Walland MJ, Rose GE. Soft tissue infection after open lacrimal surgery. Ophthalmology 1994; 101: 608-11.

2 Welham RAN, Henderson PH. Results of dacryocystorhinostomy: analysis of causes for failure. Trans Ophthalmol Soc UK 1973; 93: 601-9.

3 Welham RAN, Wulc AE Management of unsuccessful lacrimal surgery. Br $\mathrm{F}$ Ophthalmol 1987; 71: 152-7.

4 Rosner M, Rosen N. Dacryocystorhinostomy failure [Letter]. Ophthalmic Surg 1990; 21: 228.

5 Allen K, Berlin AJ. Dacryocystorhinostomy failure: association with nasolacrimal silicone intubation. Ophthalmic Surg 1989; 20: 486-9.

6 Rosen N, Sharir M, Moverman DC, Rosner M. Dacryocystorhinostomy with silicone tubes: evaluation of 253 cases. Ophthalmic Surg 1989; 20: 115-9.

7 Rose GE, Welham RAN. Jones' canalicular bypass tubes: twenty-five years' experience. Eye 1991; 5: 13-9.

8 Coden DJ, Hornblass A, Haas BD. Clinical bacteriology of dacryocystitis in adults. Ophthalmol Plast Reconstr Surg 1993; 9: 125-31.

9 Blicker JA, Buffam FV. Lacrimal sac, conjunctival and nasal culture results in dacryocystorhinostomy patients. Ophthalmol Plast Reconstr Surg 1993; 9: 43-6.

10 DiPiro JT, Cheung RPF, Bowden TA Jr, Mansberger JA. Single dose systemic antibiotic prophylaxis of surgical wound infections. Am f Surg 1986; 152: 552-9. 